\title{
Antidepressant use during pregnancy and gestational diabetes: a systematic review
}

\author{
Uso de antidepressivos durante a gestação e diabetes gestacional: uma revisão sistemática \\ Uso de antidepresivos durante el embarazo y diabetes gestacional: una revisión sistemática
}

Received: 01/28/2022 | Reviewed: 02/01/2022 | Accept: 02/02/2022 | Published: 02/05/2022

Beatriz Tianeze de Castro

ORCID: https://orcid.org/0000-0001-7167-3497 Santo Agostinho Faculty of Vitória da Conquista, Brazil

E-mail: biatianeze@ hotmail.com

Andressa Oliveira Azevedo

ORCID: https://orcid.org/0000-0001-7106-5782

Santo Agostinho Faculty of Vitória da Conquista, Brazil

E-mail: andre.azevedo1213@gmail.com

Anna Luzia Pinho Quaresma

ORCID: https://orcid.org/0000-0001-7583-2520

Santo Agostinho Faculty of Vitória da Conquista, Brazil

E-mail: annaluziapinho@gmail.com

Ana Flávia Souto Figueiredo Nepomuceno

ORCID: https://orcid.org/0000-0002-3489-0959

Federal University of Bahia, Brazil

E-mail: anaflaviafigueiredo@ outlook.com

Mariana Souto Figueiredo

ORCID: https://orcid.org/0000-0001-6702-5948

Federal University of Bahia, Brazil

E-mail: marianasoutofigueiredo@gmail.com

Lucas Santana Coelho da Silva

ORCID: https://orcid.org/0000-0003-0555-0696

Santa Cruz State University, Brazil

E-mail: lucassantana864@gmail.com

Romana Santos Gama

ORCID: https://orcid.org/0000-0002-1677-1251 Federal University of Bahia, Brazil E-mail: romanasgama@gmail.com

Caroline Tianeze de Castro

ORCID: https://orcid.org/0000-0002-9445-8842 Federal University of Bahia, Brazil E-mail: carolinetianeze@gmail.com

\begin{abstract}
A high number of women are exposed to antidepressants during pregnancy. Considering that an association between exposure to antidepressants and type 2 diabetes was found in the general population and pregnant women are inherently susceptible to insulin resistance, this study aimed to investigate data in the scientific literature on the association between antidepressant use during pregnancy and the risk of developing gestational diabetes mellitus (GDM). This systematic review was conducted according to the PRISMA guidelines. PubMed, Virtual Health Library (VHS), and Web of Science databases were searched to identify observational studies reporting the association between antidepressant use during pregnancy and GDM. Review articles, case reports, case series, clinical trials, and animal studies were excluded. In total, 67 studies were retrieved, of which 3 were included in the systematic review: one case-control and two cohort studies. According to the Newcastle-Ottawa Scale, the three studies were considered high-quality. Through this systematic review, selective serotonin reuptake inhibitors (SSRI) use during pregnancy is not significantly associated with a higher risk of developing GDM. There are still controversies about the association between serotonin and norepinephrine reuptake inhibitors (SNRI) and GDM. The use of tricyclic, tetracyclic, and atypical antidepressants by pregnant women appears to be associated with GDM. Therefore, the available information about the topic is scarce and the condition of further studies is needed.
\end{abstract}

Keywords: Antidepressive Agents; Diabetes, Gestational; Pregnancy; Systematic Review.

\section{Resumo}

Um grande número de mulheres são expostas a antidepressivos durante a gravidez. Considerando que a associação entre a exposição a antidepressivos e diabetes tipo 2 foi encontrada na população geral e as gestantes são inerentemente suscetíveis à resistência à insulina, este estudo teve como objetivo investigar dados na literatura 
científica sobre a associação entre o uso de antidepressivos durante a gravidez e o risco de desenvolver diabetes mellitus gestacional (DMG). Esta revisão sistemática foi realizada de acordo com as diretrizes do PRISMA. As bases de dados PubMed, Biblioteca Virtual em Saúde (BVS) e Web of Science foram pesquisadas para identificar estudos observacionais relatando a associação entre o uso de antidepressivos durante a gravidez e DMG. Foram excluídos artigos de revisão, relatos de casos, séries de casos, ensaios clínicos e estudos em animais. No total, 67 estudos foram recuperados, dos quais 3 foram incluídos na revisão sistemática: um caso-controle e dois estudos de coorte. De acordo com a Newcastle-Ottawa Scale, os três estudos foram considerados de alta qualidade metodológica. Por meio desta revisão sistemática, o uso de inibidores seletivos da recaptação da serotonina (ISRS) durante a gravidez não está significativamente associado a um maior risco de desenvolver DMG. Ainda há controvérsias sobre a associação entre inibidores da recaptação de serotonina e norepinefrina (IRSN) e DMG. O uso de antidepressivos tricíclicos, tetracíclicos e atípicos durante a gravidez parece estar associado ao DMG. Sendo assim, as informações disponíveis sobre o tema são escassas, sendo necessária a condução de novos estudos.

Palavras-chave: Antidepressivos; Diabetes Gestational; Gravidez; Revisão Sistemática.

\section{Resumen}

Un alto número de mujeres están expuestas a los antidepresivos durante el embarazo. Teniendo en cuenta que hay una asociación entre la exposición a los antidepresivos y la diabetes tipo 2 en la población general y que las mujeres embarazadas son inherentemente susceptibles a la resistencia a la insulina, este estudio tuvo como objetivo investigar datos en la literatura científica sobre la asociación entre el uso de antidepresivos durante el embarazo y el riesgo de desarrollar diabetes mellitus gestacional (DMG). Esta revisión sistemática fue realizada de acuerdo con las pautas del PRISMA. Se realizaron búsquedas en las bases de datos PubMed, Biblioteca Virtual em Salud (BVS) y Web of Science para identificar estudios observacionales que informaran sobre la asociación entre el uso de antidepresivos durante el embarazo y la DMG. Se excluyeron artículos de revisión, informes de casos, series de casos, ensayos clínicos y estudios en animales. En total, se recuperaron 67 estudios, de los cuales 3 se incluyeron en la revisión sistemática: un estudio de casos y controles y dos estudios de cohortes. Según la Newcastle-Ottawa Scale, los tres estudios se consideraron de alta calidad metodológica. A través de esta revisión sistemática, el uso de inhibidores selectivos de la recaptación de serotonina (ISRS) durante el embarazo no se asocia significativamente con un mayor riesgo de desarrollar DMG. Todavía hay controversias sobre la asociación entre inhibidores de la recaptación de serotonina y norepinefrina (IRSN) y DMG. El uso de antidepresivos tricíclicos, tetracíclicos y atípicos durante el embarazo parece estar asociado con DMG. Por lo tanto, la información disponible sobre el tema es escasa y se necesitan más estudios.

Palabras clave: Antidepresivo; Diabetes Gestational; Embarazo; Revisión Sistemática.

\section{Introduction}

Gestational diabetes mellitus (GDM) is the most common metabolic disturbance during pregnancy (Johns et al., 2018). It is defined as a glucose intolerance resulting in hyperglycemia manifested and diagnosed for the first time during the second or third trimester of pregnancy that was not overt diabetes before gestation (American Diabetes Association, 2020). It is estimated that GDM affects between 7-10\% of all pregnancies worldwide (Behboudi-Gandevani et al., 2019). The prevalence of GDM is rising and correlates with the increase in maternal obesity over recent decades (Johns et al., 2018).

GDM has medium and long-term consequences not only to the mother but also to the fetus. Women with GDM are at higher risk of birth complications as cesarean delivery, pre-eclampsia, preterm birth, and macrosomia, and are more likely to develop type 2 diabetes (Johns et al., 2018; Szmuilowicz et al., 2019). Furthermore, children born to women with GDM are more predisposed to type 2 diabetes, obesity, and some neurodevelopment disorders as autism spectrum disorders, intellectual disability, and attention-deficit/hyperactivity disorder (ADHD) (Chen et al., 2021; Szmuilowicz et al., 2019).

Currently, depression is a growing public health problem, given its high prevalence worldwide. Depression is a common pathology during pregnancy due to the increased vulnerability for the exacerbation of existing depression and the development of the new disease that women face in this phase (Lopez-Yarto et al., 2012). According to a systematic review and meta-analysis, the prevalence of perinatal depression is $11.9 \%$ (Woody et al., 2017).

There are several management options available for depressive disorders, however, approximately $70.0 \%$ of cases are primarily treated with antidepressants in clinical practice. Antidepressants are one of the most prescribed pharmacological classes in the world, being consumed by about $3.0 \%$ of pregnant women; moreover, over the last decade, an increase in the 
consumption of these drugs has been observed, specifically during pregnancy (Molenaar et al., 2018, 2020).

Although antidepressant use during pregnancy is usually considered safe, some studies have shown an increased risk for adverse pregnancy outcomes such as cardiovascular malformations, persistent pulmonary hypertension of the neonate, preterm birth, lower birth weight, and psychiatric disorders in offspring (Molenaar et al., 2018). Besides, an association between exposure to antidepressants and type 2 diabetes was found in the general population, which may be caused by serotonin dysregulation, damage of pancreatic $\beta$ cells, or antagonism to the histamine-1 (H1) receptor (Lupattelli et al., 2021).

Considering the high number of women exposed to these drugs during pregnancy and the potential of them to affect the health of both the pregnant woman and the fetus, it is necessary to investigate any potential risks arising from its use during pregnancy. Because pregnant women are inherently susceptible to insulin resistance, it is important to determine the metabolic safety of antidepressants in pregnant women. As long as randomized clinical trials do not allow to answer questions regarding drug safety in pregnancy due to the possibility of harmful events, observational studies are the only available source of evidence (Messerlian \& Basso, 2018). Therefore, this study aimed to investigate data in the scientific literature on the association between antidepressant use during pregnancy and the risk of developing gestational diabetes mellitus.

\section{Methodology}

This systematic review was conducted according to the Preferred Reporting Items for Systematic Reviews and MetaAnalyses (PRISMA) guidelines (Page et al., 2021).

\subsection{Eligibility criteria and outcome measures}

Original articles reporting observational studies (cohort, case-control, or cross-sectional) that investigated the association between antidepressant use at any time in pregnancy and the development of gestational diabetes mellitus were eligible for inclusion. No language or date restrictions were applied. Review articles, case reports, case series, clinical trials, and animal studies were excluded.

GDM was considered as the main outcome of interest for this systematic review, defined as a glucose intolerance resulting in hyperglycemia manifested and diagnosed for the first-time during pregnancy (American Diabetes Association, 2020) or according to the criteria adopted by each study.

\subsection{Search strategy}

Searches were conducted using PubMed, Virtual Health Library (VHS), and Web of Science databases to identify observational studies that assessed the use of antidepressants during pregnancy as a risk factor to the development of gestational diabetes mellitus from inception to December 15, 2021. Published papers registered in these databases were identified using the descriptors "gestational diabetes mellitus" and "antidepressant". Reference lists of all selected studies were reviewed to identify any studies that were not indexed in the databases but might be pertinent for inclusion in this research.

\subsection{Study selection and data extraction}

Article titles and abstracts were independently examined by 2 reviewers (BTC and AOA) for potentially relevant articles using Rayyan (Ouzzani et al., 2016), a software that helps in the screening of abstracts and titles. The studies that met the inclusion criteria in the initial phase had their eligibility confirmed by reading the full article. The articles that met all the inclusion criteria were included in the qualitative synthesis. Any disagreement about the article's inclusion was solved by a third reviewer (CTC). 
Details of the included studies were extracted independently by two reviewers (ALPQ and RSG) using a data extraction form. The extracted data include information related to publication and design, sample, age of participants, race/ethnicity, period of study completion, comorbidities, trimester of exposure, study outcome, confounding control, and statistical measures.

\subsection{Quality assessment}

The methodological quality of the included studies was assessed according to the Newcastle-Ottawa scale. This scale assesses the quality of non-randomized studies in systematic reviews, presents 3 domains, and its score is based on a star system, ranging from zero to nine stars: selection (four stars), comparability (two stars), and exposure or outcome of interest (three stars) (Wells et al., 2012). The methodological quality was classified using the following categories: low (score up to 3 stars), moderate (score between 4 and 6); and high (score of 7 or more stars) (Neal et al., 2019).

\section{Results}

\subsection{Selected studies}

The initial search returned a total of 67 manuscripts, of which 21 were duplicates. After screening titles and abstracts, 6 studies were analyzed regarding inclusion criteria and 3 were excluded. Subsequently, references of the included studies were manually searched to detect relevant articles, but none was identified. The reasons for excluding articles were: wrong study design (case report) (Yeong et al., 2014), did not analyze the association between antidepressant drugs and GDM (Hinkle et al., 2016), and wrong exposure and outcome (Katon et al., 2011). The study selection process is presented in Figure 1.

\subsection{Study characteristics}

The characteristics and findings of the reviewed studies are summarized in Table 1. Three records were eligible for inclusion in the systematic review, consisting of 1 case-control (Dandjinou et al., 2019), 1 prospective cohort (Lupattelli et al., 2021), and 1 retrospective cohort study (Wartko et al., 2019). They were published from 2011 to 2020, with 1 from Canada, 2 from the United States of America, and 1 from Norway.

In total, 241,845 women were included in the studies of which 12,583 were exposed to antidepressants during pregnancy. None of the studies reported the antidepressant exposure trimester (Dandjinou et al., 2019; Lupattelli et al., 2021; Wartko et al., 2019).

The most common antidepressant drugs evaluated by the included studies were: selective serotonin reuptake inhibitors (SSRI), such as citalopram, escitalopram, fluoxetine, fluvoxamine, paroxetine, and sertraline (Dandjinou et al., 2019; Lupattelli et al., 2021; Wartko et al., 2019); venlafaxine (Dandjinou et al., 2019; Lupattelli et al., 2021; Wartko et al., 2019); and amitriptyline (Dandjinou et al., 2019; Lupattelli et al., 2021). 
Figure 1. Study selection flowchart.

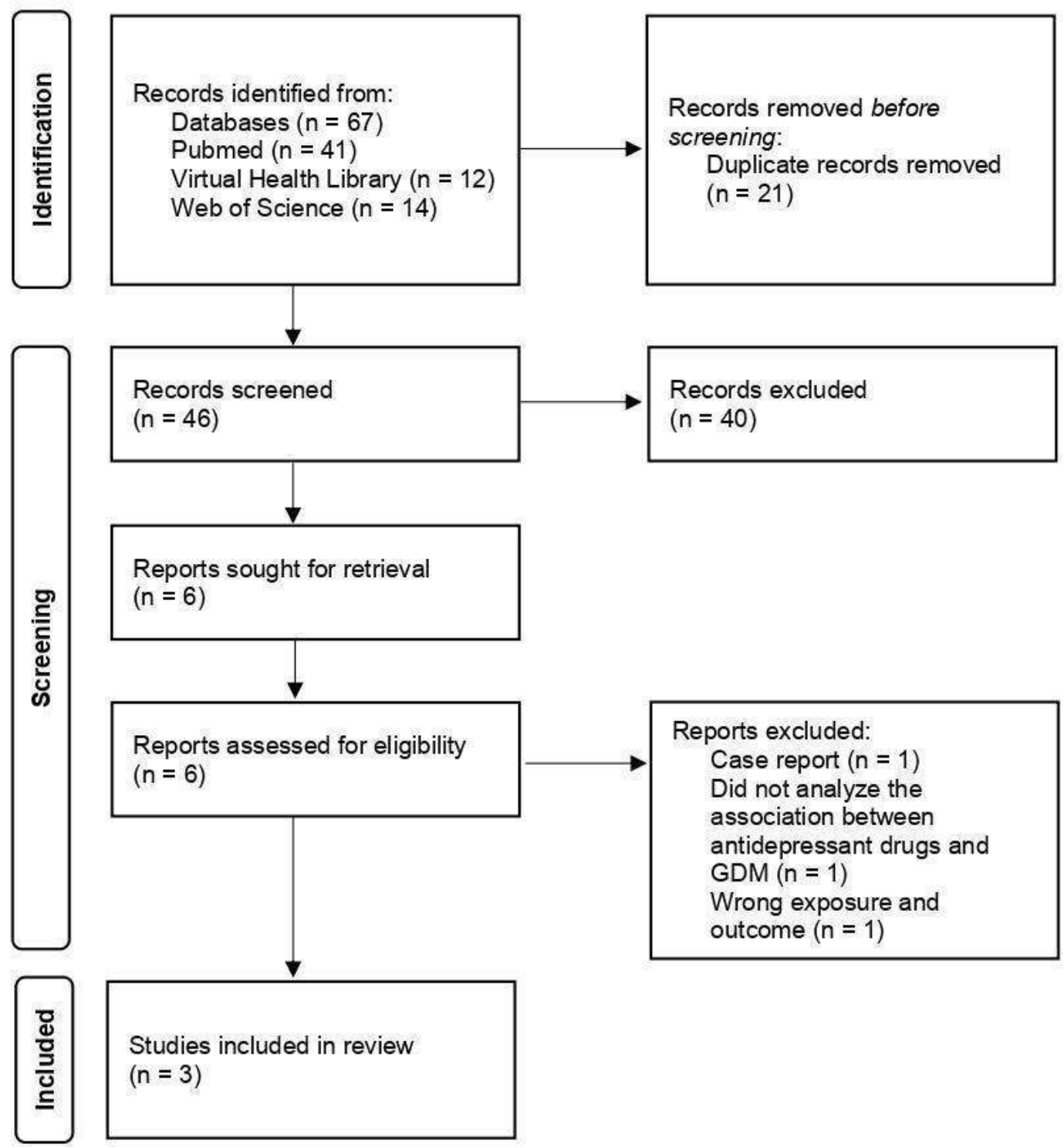

Source: own study. 
Table 1. Characteristics of the included studies.

\begin{tabular}{|c|c|c|c|c|c|c|c|c|c|c|}
\hline Study & Year & Country & Study design & $\mathbf{N}$ & $\begin{array}{c}\text { Antidepressant } \\
\text { use } \\
\text { (n) }\end{array}$ & $\begin{array}{c}\text { Antidepressant } \\
\text { drugs }\end{array}$ & $\begin{array}{c}\text { Gestational } \\
\text { diabetes } \\
\text { (n) }\end{array}$ & GDM diagnosis & Adjustment & $\begin{array}{l}\text { Statistical } \\
\text { measure }\end{array}$ \\
\hline $\begin{array}{l}\text { Dandjinou } \\
\text { et al. }\end{array}$ & 2019 & Canada & Case-control & 229,955 & $\begin{array}{c}\text { Cases: } 1,152 \\
\text { Controls: } 8,589\end{array}$ & $\begin{array}{l}\text { Amitriptyline; } \\
\text { Citalopram; } \\
\text { Fluoxetine; } \\
\text { Fluvoxamine; } \\
\text { Paroxetine; } \\
\text { Sertraline; } \\
\text { Venlafaxine }\end{array}$ & 20,905 & $\begin{array}{l}\text { GDM diagnosis codes of } \\
\text { the ICD-9 and ICD-10 } \\
\text { (ICD-9: } 250.0-250.9 \text {, } \\
648.0,648.8,790.2 \text {, } \\
775.1 \\
\text { or ICD-10: E10-E14, } \\
\text { O24, R73.0) or at least } \\
\text { one filled } \\
\text { prescription for an } \\
\text { antidiabetic drug allowed } \\
\text { during pregnancy } \\
\text { (insulin, glyburide, or } \\
\text { metformin), both after } \\
\text { the } 20^{\text {th }} \text { week of gestation }\end{array}$ & $\begin{array}{l}\text { Maternal age; } \\
\text { Receipt of social assistance; } \\
\text { Area of residence } \\
\text { (urban/rural); } \\
\text { Maternal chronic } \\
\text { comorbidities in the } 6 \\
\text { months before the } \\
\text { pregnancy: } \\
\text { Depression/anxiety; } \\
\text { Chronic hypertension; } \\
\text { Asthma; } \\
\text { Thyroid disorders; } \\
\text { Cardiovascular diseases; } \\
\text { Polycystic ovarian } \\
\text { syndrome; } \\
\text { Physician visits, } \\
\text { hospitalizations, or } \\
\text { emergency department } \\
\text { visits; } \\
\text { Use of other medications; } \\
\text { Use of medications related } \\
\text { to chronic comorbidities }\end{array}$ & $\begin{array}{c}\text { Amitriptyline: OR } \\
1.52 \text { (95\%CI } 1.25- \\
1.84) ; \\
\text { Citalopram: OR } \\
\text { 1.11 (95\%CI 0.95- } \\
1.29) ; \\
\text { Fluoxetine: OR } \\
\text { 0.85 (95\%CI 0.57- } \\
\text { 1.25); } \\
\text { Fluvoxamine: OR } \\
\text { 1.01 (95\%CI 0.50- } \\
2.03) ; \\
\text { Paroxetine: OR } \\
1.13 \text { (95\%CI 0.94- } \\
1.36) ; \\
\text { Sertraline: OR } \\
\text { 1.01 (95\%CI 0.80- } \\
1.28) ; \\
\text { Venlafaxine: OR } \\
\text { 1.27 (95\%CI 1.09- } \\
\text { 1.49); } \\
\text { Other: OR 1.04 } \\
\text { (95\%CI 0.82- } \\
1.31) ; \\
\geq 2 \text { AD: OR 1.31 } \\
\text { (95\%CI 1.10- } \\
1.56)\end{array}$ \\
\hline $\begin{array}{l}\text { Lupattelli } \\
\text { et al. }\end{array}$ & 2021 & Norway & $\begin{array}{l}\text { Prospective } \\
\text { cohort }\end{array}$ & 6,647 & 897 & $\begin{array}{c}\text { Group 1: } \\
\text { All SSRI; } \\
\text { Venlafaxine; } \\
\text { Duloxetine; } \\
\text { Clomipramine } \\
\text { Group 2: }\end{array}$ & 84 & $\begin{array}{l}\text { Fasting plasma glucose } \\
\text { level } \geq 7.0 \mathrm{mmoL} / \mathrm{L} \text {; or } 2 \\
\text { hours after glucose } \\
\text { challenge test glucose } \\
\text { level } \geq 11.1 \mathrm{mmoL} / \mathrm{L}\end{array}$ & $\begin{array}{l}\text { Parity; } \\
\text { Marital status; } \\
\text { Maternal education; } \\
\text { Gross yearly income; } \\
\text { Smoking; } \\
\text { Alcohol use; } \\
\text { Physical activity in the } 3\end{array}$ & $\begin{array}{l}\text { Group 1: } \\
\text { RR 1.10 } \\
\text { (95\%CI: } 0.60- \\
\text { 2.10) } \\
\text { Group 2: } \\
\text { RR 3.90 }\end{array}$ \\
\hline
\end{tabular}


Research, Society and Development, v. 11, n. 2, e53911226278, 2022

(CC BY 4.0) | ISSN 2525-3409 | DOI: http://dx.doi.org/10.33448/rsd-v11i2.26278

\begin{tabular}{|c|c|c|c|c|c|c|c|c|c|c|}
\hline & & & & & & $\begin{array}{l}\text { Amitriptyline; } \\
\text { Trimipramine; } \\
\text { Maprotiline; } \\
\text { Nortriptyline; } \\
\text { Mianserin; } \\
\text { Mirtazapine; } \\
\text { Doxepin; } \\
\text { Nefazodone }\end{array}$ & & & $\begin{array}{l}\text { months before pregnancy; } \\
\text { BMI at the time of } \\
\text { pregnancy start; } \\
\text { Self-reported use in } \\
\text { the 6-month period before } \\
\text { pregnancy of non-steroidal } \\
\text { anti-inflammatory } \\
\text { medication, opioid } \\
\text { analgesics, acetaminophen, } \\
\text { benzodiazepines, } \\
\text { antipsychotics, mood } \\
\text { stabilizers, and } \\
\text { antiepileptics; } \\
\text { Obstetric comorbidity index; } \\
\text { Life Time History of Major } \\
\text { Depression }\end{array}$ & $\begin{array}{c}\text { (95\%CI: } 1.20- \\
11.70)\end{array}$ \\
\hline $\begin{array}{l}\text { Wartko et } \\
\text { al. }\end{array}$ & 2019 & $\begin{array}{l}\text { United } \\
\text { States of } \\
\text { America }\end{array}$ & $\begin{array}{c}\text { Retrospective } \\
\text { Cohort }\end{array}$ & 2,845 & 1634 & $\begin{array}{c}\text { SSRI; } \\
\text { Bupropion; } \\
\text { Venlafaxine }\end{array}$ & 239 & $\begin{array}{l}\text { ICD-9 } 648.8 \text { from } 16 \\
\text { weeks gestation to } \\
\text { delivery or one code at } \\
\text { the delivery } \\
\text { hospitalization, and } \\
\text { through blood glucose } \\
\text { levels }(\mathrm{mg} / \mathrm{dL}) \text { screening }\end{array}$ & $\begin{array}{l}\text { Birth year; } \\
\text { Maternal age; } \\
\text { Baby's sex; } \\
\text { Medicaid insurance } \\
\text { coverage; } \\
\text { Smoking and substance use } \\
\text { disorder diagnoses; } \\
\text { Mental health diagnoses; } \\
\text { Psychotropic and other } \\
\text { prescription medication fills; } \\
\text { Utilization of } \\
\text { psychotherapy, psychiatry, } \\
\text { and inpatient psychiatric } \\
\text { hospitalization }\end{array}$ & $\begin{array}{l}\text { Venlafaxine } \\
\text { RR } 1.52 \\
\text { (95\%CI: } 0.87- \\
\text { 2.68) } \\
\text { SSRI: } \\
\text { RR 1.10 } \\
\text { (95\%CI: } 0.84- \\
\text { 1.45) } \\
\text { Bupropion: } \\
\text { RR 1.07 } \\
\text { (95\%CI: } 0.63- \\
\text { 1.81) }\end{array}$ \\
\hline
\end{tabular}


The definition of GDM was different between the studies: one study used the diagnosis codes of the 9th or 10th editions of the International Classification of Diseases (ICD) related to GDM or at least one filled prescription for an antidiabetic drug allowed during pregnancy, both after the $20^{\text {th }}$ week of pregnancy (Dandjinou et al., 2019); another one required at least two codes of ICD-9 648.8 from 16 weeks gestation to delivery or one code at the delivery hospitalization, and also assessed blood glucose levels (mg/dL) for GDM screening (Wartko et al., 2019); and one study adopted fasting plasma glucose level $\geq 7.0 \mathrm{mmoL} / \mathrm{L}$ or 2 hours after glucose challenge test glucose level $\geq 11.1 \mathrm{mmoL} / \mathrm{L}$ at gestational weeks $24-28$ as diagnostic criteria of GDM (Lupattelli et al., 2021).

\subsection{Quality of the included studies}

According to the Newcastle-Ottawa Scale, the three studies were considered as high quality, of which one was "nine stars" (Dandjinou et al., 2019) and two were "eight stars" (Lupattelli et al., 2021; Wartko et al., 2019) (Table 2).

Table 2. Quality assessment according to the Newcastle-Ottawa Scale.

\begin{tabular}{lccccc}
\hline \multicolumn{1}{c}{ Study } & Selection & Comparability & Outcome & Total score & Quality \\
\hline Dandjinou et al. (2019) & $* * * *$ & $* *$ & $* * *$ & 9 & High \\
Lupattelli et al. (2021) & $* * * *$ & $* *$ & $* *$ & 8 & High \\
Wartko et al. (2019) & $* * * *$ & $* *$ & $* *$ & 8 & High \\
\hline
\end{tabular}

Source: own study.

\section{Discussion}

The main results found in the present systematic review are in line with studies in the general population that have shown the frequent use of antidepressants around the world, a fact that may be due to the increase in mental disorders (MD) that are currently configured as an important public health problem (Santos et al., 2019). As for the profile of affected individuals, a survey showed that women are more likely to develop MD, which may be associated with greater exposure and use of antidepressants, including during pregnancy (Haque et al., 2022).

Concerning maternal exposure to antidepressants during pregnancy, this study suggests that the use of these drugs may impact the development of GDM depending on the antidepressant used. Our review yielded three observational studies, which evaluated a variety of antidepressants. The most commonly used antidepressants during pregnancy are SSRIs and serotonin and norepinephrine reuptake inhibitors (SNRIs) such as venlafaxine and duloxetine (Dubovicky et al., 2017).

SSRIs act blocking the reuptake of serotonin as well as enhancing, and prolonging the serotonergic neurotransmission. They are currently the first-line agents for the treatment of depression (Sheffler \& Abdijadid, 2021). All of the included studies evaluated exposure to SSRI in pregnancy and GDM (Dandjinou et al., 2019; Lupattelli et al., 2021; Wartko et al., 2019). Dandjinou et al (2019) conducted a case-control study nested within the Quebec Pregnancy Cohort with 229,955 pregnant women, between 1998 to 2015. The authors observed that exposure to citalopram (OR 1.11; 95\%CI 0.95-1.29), fluoxetine (OR 0.85; 95\%CI 0.57-1.25), fluvoxamine (OR 1.01; 95\%CI 0.50-2.03), paroxetine (OR 1.13; 95\%CI 0.94-1.36), and sertraline (OR $1.01 ; 95 \%$ CI $0.80-1.28$ ) were not statistically associated with the development of GDM.

Similarly, an American retrospective cohort study with data from 2,845 pregnant women from January 1, 2001, through December 31, 2014, did not find a statistically significant association between SSRI (citalopram, fluoxetine, fluvoxamine, paroxetine, and sertraline) use during pregnancy and GDM (RR 1.10; 95\%CI 0.84-1.45) (Wartko et al., 2019). A national Norwegian prospective cohort of 6,647 pregnant women between 1999 and 2008 evaluated exposure to SSRI, among them citalopram, fluoxetine, fluvoxamine, paroxetine, and sertraline, and venlafaxine, duloxetine, and clomipramine and also 
did not reveal an association with GDM (RR 1.10; 95\%CI: 0.60-2.10) (Lupattelli et al., 2021).

SNRIs block serotonin and norepinephrine reuptake in the synapse, increasing postsynaptic receptors' stimulation (Sheffler \& Abdijadid, 2021). Regarding exposure to SNRI during pregnancy, the literature findings are still controversial and scarce. While one study found an increased odds of GDM among pregnant women who used venlafaxine (OR 1.27; 95\%CI 1.09-1.49) (Dandjinou et al., 2019), another one did not observe a significant increase in the risk of the outcome in women exposed to venlafaxine in pregnancy (RR 1.52; 95\%CI: 0.87-2.68) (Wartko et al., 2019). Nonetheless, Dandjinou et al.'s study has several limitations as a majority of Caucasian population, the inclusion of only pregnancies of non-overweight/non-obese women, and underestimations that may limit its generalizability. Moreover, there is the possibility of residual confounding by indication related to the underlying depression and by the impossibility of adjustment for some lifestyle variables such as smoking, weight gain, BMI, and physical activity practice due to missing in the database analyzed.

Other classes of antidepressants analyzed by the studies included in the present systematic review were tricyclic, tetracyclic, and atypical antidepressants. Tricyclic antidepressants (TCAs), such as amitriptyline, doxepin, nortriptyline, imipramine, and trimipramine, were the first antidepressants marketing for the management of the major depressive disorder. They block the reuptake of serotonin and norepinephrine in presynaptic terminals, which leads to increased concentration of these neurotransmitters in the synaptic cleft. Additionally, they act as competitive antagonists on post-synaptic alpha cholinergic (alpha1 and alpha2), muscarinic, and histaminergic receptors (H1) (Moraczewski \& Aedma, 2021).

Tetracyclic antidepressants (TeCAs), as maprotiline and mianserin, were developed later and are used for similar clinical purposes and have the same mechanisms of action that TCAs. Before the introduction of SSRIs, TCAs and TeCAs were widely used by pregnant women. They are as effective as SSRIs to treat the major depressive disorder, however, cause more significant adverse effects due to their anticholinergic activity and a lower threshold for overdose. Thus, TCAs and TeCAs are typically not used as first-line treatment of major depression; furthermore, the use of TCAs during pregnancy has been correlated with congenital malformations and, therefore, TCAs are not generally considered safe to use during pregnancy (Moraczewski \& Aedma, 2021; Ornoy et al., 2017).

Atypical antidepressants include bupropion, mirtazapine, and nefazodone (Ornoy et al., 2017; Sheffler \& Abdijadid, 2021). They have various mechanisms of action; bupropion inhibits the reuptake of dopamine and norepinephrine at the presynaptic cleft, while mirtazapine blocks alpha-2 adrenergic receptors on the cell bodies and nerve terminals, promoting the release of norepinephrine into the synapse, and antagonizes serotonin receptors, which increase norepinephrine and dopamine in the brain's cortical regions (Sheffler \& Abdijadid, 2021). Their use during pregnancy does not increase the risk of congenital anomalies (Ornoy et al., 2017).

The use of TCAs, TeCAs, and atypical antidepressants by pregnant women appears to be associated with GDM. A Canadian case-control study found an odd 52.0\% higher GDM among women exposed to amitriptyline during pregnancy (Dandjinou et al., 2019). A Norwegian prospective cohort evaluated the use of amitriptyline, trimipramine, maprotiline, nortriptyline, mianserin, mirtazapine, doxepin, and nefazodone during pregnancy and observed risk of GDM 3.90 higher between women exposed to these drugs (Lupattelli et al., 2021). As limitations of this study are the self-report of depressive/anxiety disorders before and/or during pregnancy and antidepressants use which may underestimate these measures, low response rate, low statistical power, and GDM misclassification.

The biological plausibility of the association between antidepressant exposure during pregnancy and GDM is not fully understood. The scientific literature points out that antidepressants may be involved in diabetes development by acting on glucose homeostasis, increasing cellular insulin resistance, decreasing pancreatic insulin secretion, or acting indirectly on insulin via weight gain (Dandjinou et al., 2019; Hennings et al., 2012; Isaac et al., 2013; Kozhimannil et al., 2009; Molyneaux 
et al., 2016; Oyebode et al., 2012; Reis \& Källén, 2010; Wartko et al., 2019).

Antidepressants may induce hyperglycemia once the majority of these drugs target serotonin, which is involved in glucose homeostasis (Carvalho et al., 2004). Moreover, antidepressants inhibit insulin's pathway, enabling GDM development, since serotonin plays a role in establishing natural insulin resistance in pregnancy (Baeyens et al., 2016; Levkovitz et al., 2007). Findings such as dysregulation of glucose metabolism, increase in body mass index, decrease in adiponectin levels, in addition to changes in the gene encoding the $\beta 3$ adrenergic receptor (target of norepinephrine) may also justify insulin resistance in pregnant women using antidepressants (Kozhimannil et al., 2009; Oyebode et al., 2012; Reis \& Källén, 2010). Furthermore, the use of antidepressants can compromise the mitochondrial function of pancreatic $\beta$ cells, which therefore reduces insulin secretion and increases apoptosis of these cells (Dandjinou et al., 2019; Wartko et al., 2019).

There is a greater propensity to gain weight during pregnancy, which is one of the adverse effects of the use of antidepressants eider. Also, women with antenatal depression use to have lower healthy and traditional dietary pattern scores than women without high levels of antenatal depression symptoms. These factors added to the physiological changes, which tend to occur in this phase of life, increase the risk of GDM (Dandjinou et al., 2019; Molyneaux et al., 2016; Wartko et al., 2019).

TCAs appear to affect glucose dysregulation and weight gain more often than SSRIs and SNRIs due to their different affinity to serotoninergic, noradrenergic, and histamine receptors. In fact, SSRIs may induce hypoglycemia while antidepressants such as amitriptyline and venlafaxine may lead to hyperglycemia (Dandjinou et al., 2019).

As for the profile of pregnant women who participated in the studies included in this review, women with an average age between 18 and 34 years and residents of the urban area stood out. Among the characteristics associated with the development of GDM, pre-gestational weight, the presence of pre-existing diseases such as hypertension and obesity, and maternal education level stood out (Dandjinou et al., 2019).

Regarding the countries in which the selected studies took place, epidemiological studies have shown that residents of locations with better socioeconomic conditions, such as Canada, the United States of America, and Norway, tend to use more antidepressants when compared to residents of other regions, which occurs due to greater access to diagnosis as well as health services. In addition, in these countries, there has been an increase in the number of pregnant women with depression, with a prevalence of up to $30 \%$, which may have contributed to the conduction of studies in these locations, given the repercussions of this problem on public health (Pereira \& Lovisi, 2008).

In addition, there is a need to conduct studies on the subject also in developing countries, since this knowledge gap can contribute to inequities in mental health and worsening of clinical conditions, since many individuals with clinically relevant depressive symptoms may not receive any type of treatment (Gonçalves et al., 2018).

Despite the lack of more robust studies that describe the possible impacts of antidepressant use during pregnancy, the existing results so far point out the need to maintain drug therapy for mental health care. Since the worsening of mental disorders during pregnancy also presents imminent health risks, especially for residents of developing countries, where the increased risk of maternal suicide has been highlighted, and for children, cognitive delay and in the development of motor skills, in addition to the difficulty of interaction between mother and child (Oyebode et al., 2012).

This systematic review presents strengths and limitations. This is a comprehensive assessment of the evidence, incorporating all available published studies about antidepressant use during pregnancy and GDM development. Strengths also include the use of the Newcastle-Ottawa Scale to assess the methodological quality of the included studies, the high methodological quality of the selected studies, the relevance of the theme considering the high prevalence of antidepressant use in pregnancy as well as GDM. 
An important limitation of this research is the low number of articles included which may affect the generalization of the findings given the low statistical power of some studies, regional differences, and the fact that the studies took place in developed countries, minimizing the socioeconomic influence for the development of DMG. However, it is noteworthy that among the strengths are:

Another limitation is the different ways to obtain information on the use of antidepressants. The articles included in this systematic review obtained this information through data from health insurance systems (Dandjinou et al., 2019; Wartko et al., 2019) and self-report via questionnaires application (Lupattelli et al., 2021), which favors the recall bias and may underestimate or overestimate the exposure. Furthermore, the studies used different approaches to define GDM, which may limit comparability between studies.

\section{Conclusion}

Considering the limitations previously stated, the findings of this systematic review suggest that SSRI use during pregnancy is not associated with an increased risk of GDM, whereas the use of TCAs, TeCAs, and atypical antidepressants by pregnant women probably is associated with GDM. Regarding SNRIs, there are still controversies about their association with GDM.

Nevertheless, the available information in the literature is scarce and further studies to clarify these associations and elucidate the causal relationship are needed. In addition, the importance of conducting more studies on the subject is highlighted, given that the use of drugs during pregnancy, as well as the associated outcomes, are of great value to public health.

Therefore, future studies based in cohorts and using real-world evidence should be conducted to improve the evidence about the topic and help to address the role of antidepressants on GDM.

\section{References}

American Diabetes Association. (2020). 2. Classification and Diagnosis of Diabetes: Standards of Medical Care in Diabetes-2021. Diabetes Care, 44(Supplement_1), S15-S33. https://doi.org/10.2337/dc21-S002

Baeyens, L., Hindi, S., Sorenson, R. L., \& German, M. S. (2016). 3 -Cell adaptation in pregnancy. Diabetes, Obesity and Metabolism, 18(S1), 63-70. https://doi.org/10.1111/dom.12716

Behboudi-Gandevani, S., Amiri, M., Bidhendi Yarandi, R., \& Ramezani Tehrani, F. (2019). The impact of diagnostic criteria for gestational diabetes on its prevalence: A systematic review and meta-analysis. Diabetology \& Metabolic Syndrome, 11(1), 11. https://doi.org/10.1186/s13098-019-0406-1

Carvalho, F., Barros, D., Silva, J., Rezende, E., Soares, M., Fregoneze, J., \& De Castro e Silva, E. (2004). Hyperglycemia induced by acute central fluoxetine administration: Role of the central CRH system and 5-HT3 receptors. Neuropeptides, 38(2), 98-105. https://doi.org/10.1016/j.npep.2004.04.004

Chen, S., Zhao, S., Dalman, C., Karlsson, H., \& Gardner, R. (2021). Association of maternal diabetes with neurodevelopmental disorders: Autism spectrum disorders, attention-deficit/hyperactivity disorder and intellectual disability. International Journal of Epidemiology, 50(2), 459-474. https://doi.org/10.1093/ije/dyaa212

Dandjinou, M., Sheehy, O., \& Bérard, A. (2019). Antidepressant use during pregnancy and the risk of gestational diabetes mellitus: A nested case-control study. BMJ Open, 9(9), e025908. https://doi.org/10.1136/bmjopen-2018-025908

Dubovicky, M., Belovicova, K., Csatlosova, K., \& Bogi, E. (2017). Risks of using SSRI / SNRI antidepressants during pregnancy and lactation. Interdisciplinary Toxicology, 10(1), 30-34. https://doi.org/10.1515/intox-2017-0004

Gonçalves, A. M. C., Teixeira, M. T. B., Gama, J. R. de A., Lopes, C. S., Silva, G. A. e, Gamarra, C. J., Duque, K. de C. D., \& Machado, M. L. S. M. (2018). Prevalência de depressão e fatores associados em mulheres atendidas pela Estratégia de Saúde da Família. Jornal Brasileiro de Psiquiatria, 67, 101-109. https://doi.org/10.1590/0047-2085000000192

Haque, M. R., Khan, M. M. A., Rahman, M. M., Rahman, M. S., \& Begum, S. A. (2022). Mental health status of informal waste workers during the COVID19 pandemic in Bangladesh. PLOS ONE, 17(1), e0262141. https://doi.org/10.1371/journal.pone.0262141

Hennings, J. M., Schaaf, L., \& Fulda, S. (2012). Glucose Metabolism and Antidepressant Medication. Current Pharmaceutical Design, 18(36), 5900-5919. 
Hinkle, S. N., Buck Louis, G. M., Rawal, S., Zhu, Y., Albert, P. S., \& Zhang, C. (2016). A longitudinal study of depression and gestational diabetes in pregnancy and the postpartum period. Diabetologia, 59(12), 2594-2602. https://doi.org/10.1007/s00125-016-4086-1

Isaac, R., Boura-Halfon, S., Gurevitch, D., Shainskaya, A., Levkovitz, Y., \& Zick, Y. (2013). Selective Serotonin Reuptake Inhibitors (SSRIs) Inhibit Insulin Secretion and Action in Pancreatic $\beta$ Cells*. Journal of Biological Chemistry, 288(8), 5682-5693. https://doi.org/10.1074/jbc.M112.408641

Johns, E. C., Denison, F. C., Norman, J. E., \& Reynolds, R. M. (2018). Gestational Diabetes Mellitus: Mechanisms, Treatment, and Complications. Trends in Endocrinology \& Metabolism, 29(11), 743-754. https://doi.org/10.1016/j.tem.2018.09.004

Katon, J. G., Russo, J., Gavin, A. R., Melville, J. L., \& Katon, W. J. (2011). Diabetes and Depression in Pregnancy: Is There an Association? Journal of Women's Health, 20(7), 983-989. https://doi.org/10.1089/jwh.2010.2662

Kozhimannil, K. B., Pereira, M. A., \& Harlow, B. L. (2009). Association between diabetes and perinatal depression among low-income mothers. JAMA, 301(8), 842-847. https://doi.org/10.1001/jama.2009.201

Levkovitz, Y., Ben-shushan, G., Hershkovitz, A., Isaac, R., Gil-Ad, I., Shvartsman, D., Ronen, D., Weizman, A., \& Zick, Y. (2007). Antidepressants induce cellular insulin resistance by activation of IRS-1 kinases. Molecular and Cellular Neuroscience, 36(3), 305-312. https://doi.org/10.1016/j.mcn.2007.05.009

Lopez-Yarto, M., Ruiz-Mirazo, E., Holloway, A. C., Taylor, V. H., \& McDonald, S. D. (2012). Do psychiatric medications, especially antidepressants, adversely impact maternal metabolic outcomes? Journal of Affective Disorders, 141(2-3), 120-129. https://doi.org/10.1016/j.jad.2012.01.043

Lupattelli, A., Barone-Adesi, F., \& Nordeng, H. (2021). Association between antidepressant use in pregnancy and gestational diabetes mellitus: Results from the Norwegian Mother, Father and Child Cohort Study. Pharmacoepidemiology and Drug Safety. https://doi.org/10.1002/pds.5388

Messerlian, C., \& Basso, O. (2018). Cohort studies in the context of obstetric and gynecologic research: A methodologic overview. Acta Obstetricia et Gynecologica Scandinavica, 97(4), 371-379. https://doi.org/10.1111/aogs.13272

Molenaar, N. M., Bais, B., Lambregtse-van den Berg, M. P., Mulder, C. L., Howell, E. A., Fox, N. S., Rommel, A.-S., Bergink, V., \& Kamperman, A. M. (2020). The international prevalence of antidepressant use before, during, and after pregnancy: A systematic review and meta-analysis of timing, type of prescriptions and geographical variability. Journal of Affective Disorders, 264, 82-89. https://doi.org/10.1016/j.jad.2019.12.014

Molenaar, N. M., Kamperman, A. M., Boyce, P., \& Bergink, V. (2018). Guidelines on treatment of perinatal depression with antidepressants: An international review. Australian \& New Zealand Journal of Psychiatry, 52(4), 320-327. https://doi.org/10.1177/0004867418762057

Molyneaux, E., Poston, L., Khondoker, M., \& Howard, L. M. (2016). Obesity, antenatal depression, diet and gestational weight gain in a population cohort study. Archives of Women's Mental Health, 19(5), 899-907. https://doi.org/10.1007/s00737-016-0635-3

Moraczewski, J., \& Aedma, K. K. (2021). Tricyclic Antidepressants. In StatPearls [Internet]. StatPearls Publishing. https://www.ncbi.nlm.nih.gov/books/NBK557791/

Neal, B. S., Lack, S. D., Lankhorst, N. E., Raye, A., Morrissey, D., \& van Middelkoop, M. (2019). Risk factors for patellofemoral pain: A systematic review and meta-analysis. British Journal of Sports Medicine, 53(5), 270-281. https://doi.org/10.1136/bjsports-2017-098890

Ornoy, A., Weinstein-Fudim, L., \& Ergaz, Z. (2017). Antidepressants, Antipsychotics, and Mood Stabilizers in Pregnancy: What Do We Know and How Should We Treat Pregnant Women with Depression. Birth Defects Research, 109(12), 933-956. https://doi.org/10.1002/bdr2.1079

Ouzzani, M., Hammady, H., Fedorowicz, Z., \& Elmagarmid, A. (2016). Rayyan-A web and mobile app for systematic reviews. Systematic Reviews, 5(1). https://doi.org/10.1186/s13643-016-0384-4

Oyebode, F., Rastogi, A., Berrisford, G., \& Coccia, F. (2012). Psychotropics in pregnancy: Safety and other considerations. Pharmacology \& Therapeutics, 135(1), 71-77. https://doi.org/10.1016/j.pharmthera.2012.03.008

Page, M. J., McKenzie, J. E., Bossuyt, P. M., Boutron, I., Hoffmann, T. C., Mulrow, C. D., Shamseer, L., Tetzlaff, J. M., Ak1, E. A., Brennan, S. E., Chou, R., Glanville, J., Grimshaw, J. M., Hróbjartsson, A., Lalu, M. M., Li, T., Loder, E. W., Mayo-Wilson, E., McDonald, S., ... Moher, D. (2021). The PRISMA 2020 statement: An updated guideline for reporting systematic reviews. BMJ, 372, n71. https://doi.org/10.1136/bmj.n71

Pereira, P. K., \& Lovisi, G. M. (2008). Prevalência da depressão gestacional e fatores associados. Archives of Clinical Psychiatry (São Paulo), 35, 144-153. https://doi.org/10.1590/S0101-60832008000400004

Reis, M., \& Källén, B. (2010). Delivery outcome after maternal use of antidepressant drugs in pregnancy: An update using Swedish data. Psychological Medicine, 40(10), 1723-1733. https://doi.org/10.1017/S0033291709992194

Santos, G. de B. V. dos, Alves, M. C. G. P., Goldbaum, M., Cesar, C. L. G., \& Gianini, R. J. (2019). Prevalência de transtornos mentais comuns e fatores associados em moradores da área urbana de São Paulo, Brasil. Cadernos de Saúde Pública, 35. https://doi.org/10.1590/0102-311X00236318

Sheffler, Z. M., \& Abdijadid, S. (2021). Antidepressants. In StatPearls [Internet]. StatPearls Publishing. http://europepmc.org/abstract/MED/30844209

Szmuilowicz, E. D., Josefson, J. L., \& Metzger, B. E. (2019). Gestational Diabetes Mellitus. Endocrinology and metabolism clinics of North America, 48(3), 479-493. https://doi.org/10.1016/j.ecl.2019.05.001

Wartko, P. D., Weiss, N. S., Enquobahrie, D. A., Chan, K. C. G., Stephenson-Famy, A., Mueller, B. A., \& Dublin, S. (2019). Antidepressant continuation in pregnancy and risk of gestational diabetes. Pharmacoepidemiology and Drug Safety, 28(9), 1194-1203. https://doi.org/10.1002/pds.4799

Wells, G., Shea, B., O’Connell, D., Peterson, J., Welch, V., Losos, M., \& Tugwell, P. (2012). The Newcastle-Ottawa Scale (NOS) for assessing the quality of nonrandomised studies in meta-analyses. http://www.ohri.ca/programs/clinical_epidemiology/oxford.asp 
Research, Society and Development, v. 11, n. 2, e53911226278, 2022

(CC BY 4.0) | ISSN 2525-3409 | DOI: http://dx.doi.org/10.33448/rsd-v11i2.26278

Woody, C. A., Ferrari, A. J., Siskind, D. J., Whiteford, H. A., \& Harris, M. G. (2017). A systematic review and meta-regression of the prevalence and incidence of perinatal depression. Journal of Affective Disorders, 219, 86-92. https://doi.org/10.1016/j.jad.2017.05.003

Yeong, C., Worsley, R., Gilbert, H., \& Kulkarni, J. (2014). Gestational diabetes in women with mental illness. The Australian and New Zealand journal of psychiatry, 48. https://doi.org/10.1177/0004867414528591 